University of Nebraska - Lincoln

DigitalCommons@University of Nebraska - Lincoln

University of Nebraska Press -- Sample Books

and Chapters

University of Nebraska Press

Spring 2013

Racial Science in Hitler's New Europe, 1938-1945

Anton Weiss-Wendt

Rory Yeomans

Follow this and additional works at: https://digitalcommons.unl.edu/unpresssamples

Weiss-Wendt, Anton and Yeomans, Rory, "Racial Science in Hitler's New Europe, 1938-1945" (2013).

University of Nebraska Press -- Sample Books and Chapters. 189.

https://digitalcommons.unl.edu/unpresssamples/189

This Article is brought to you for free and open access by the University of Nebraska Press at DigitalCommons@University of Nebraska - Lincoln. It has been accepted for inclusion in University of Nebraska Press -- Sample Books and Chapters by an authorized administrator of DigitalCommons@University of Nebraska - Lincoln. 


\section{Racial Science in Hitler's New Europe, 1938-1945}


CRITICAL STUDIES IN THE HISTORY OF ANTHROPOLOGY Series Editors: Regna Darnell | Stephen O.Murray 


\title{
RACIAL SCIENCE
}

\author{
IN HITLER'S \\ NEW EUROPE, \\ 1938-1945
}

Edited by Anton Weiss-Wendt and Rory Yeomans

University of Nebraska Press : Lincoln and London 
(C) 2013 by the Board of Regents of the University of Nebraska

All rights reserved

Manufactured in the United States of America

()

This book is published in association with the Center for the Study of the Holocaust and Religious Minorities in Oslo,

Norway.

Library of Congress Cataloging-in-Publication Data Racial science in Hitler's new Europe, 1938-1945 / edited by Anton Weiss-Wendt and Rory Yeomans.

pages $\mathrm{cm}$. - (Critical studies in the history of anthropology)

Includes bibliographical references and index.

ISBN 978-0-8032-4507-5 (pbk.: alk. paper) 1. Physical

anthropology-Europe-History-2oth century.

2. Racism in anthropology-Europe-History-2oth century. 3. National socialism and medicine-Europe-

History-2oth century. 4. National socialism and science-Europe-History-2oth century. 5. Racism in medicine-Europe-History-2oth century. 6. EugenicsEurope-History—2oth century. 7. Race-ResearchGermany-History-2oth century. 8. Germany-Politics and government-1933-1945.9. Germany-Race relations.

I. Weiss-Wendt, Anton, 1973- II. Yeomans, Rory. GN50.45.E85R33 2013 305.800943 - dc23 2012050639

Set in Arno Pro by Laura Wellington.

Designed by Ashley Muehlbauer. 
In Memoriam:

Karin Isakova

Elisabeth Weiss-Wendt

Jeanne Margaret Pearson

Margaret Henderson Macdonald 


\section{Contents}

Series Editors' Introduction $\ldots \ldots \ldots \ldots \ldots \ldots \ldots \ldots \ldots \ldots \ldots \ldots \ldots \ldots$

Acknowledgments $\ldots \ldots \ldots \ldots \ldots \ldots \ldots \ldots \ldots \ldots \ldots \ldots \ldots \ldots \ldots \ldots$

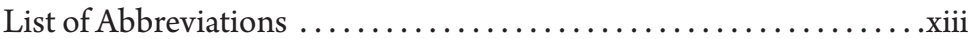

Introduction: The Holocaust and Historiographical

Debates on Racial Science. ..........................

ANTON WEISS-WENDT AND RORY YEOMANS

1. Defining “(Un)Wanted Population Addition”: Anthropology,

Racist Ideology, and Mass Murder in the Occupied East ..........35

ISABEL HEINEMANN

2. Preserving the "Master Race": ss Reproductive and

Family Policies during the Second World War ..............60

AMY CARNEY

3. Germanic Brothers: The Dutch and the

Germanization of the Occupied East.................. 83

GERALDIEN VON FRIJTAG DRABBE KÜNZEL

4. Pure-Blooded Vikings and Peasants: Norwegians

in the Racial Ideology of the $s s \ldots \ldots \ldots \ldots \ldots \ldots \ldots \ldots \ldots \ldots$

TERJE EMBERLAND

5. "Nordic-Germanic" Dreams and National Realities: A Case

Study of the Danish Region of Sønderjylland, 1933-1945 . . . . . . . 129 STEFFEN WERTHER

6. Eugenics into Science: The Nazi Period in Austria, $1938-1945 . . .1 .150$

THOMAS MAYER 
7. Biological Racism and Antisemitism as Intellectual

Constructions in Italian Fascism: The Case of Telesio

Interlandi and La difesa della razza .................... 175

ELISABETTA CASSINA WOLFF

8. Eradicating "Undesired Elements": National

Regeneration and the Ustasha Regime's Program

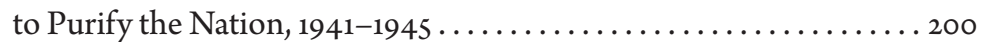

RORY YEOMANS

9. "If Our Race Did Not Exist, It Would Have to Be Created":

Racial Science in Hungary, $1940-1944$. . . . . . . . . . . . . . 237

MARIUS TURDA

10. In the Shadow of Ethnic Nationalism:

Racial Science in Romania ......................... 259

VLADIMIR SOLONARI

11. Building Hitler's "New Europe”: Ethnography and

Racial Research in Nazi-Occupied Estonia . ............. 287

ANTON WEISS-WENDT

12. In Pursuit of Biological Purity: Eugenics and Racial

Paradigms in Nazi-Occupied Latvia, $1941-1945 \ldots \ldots \ldots \ldots \ldots \ldots . \ldots 320$ BJÖRN M. FELDER

13. The Eternal Voice of the Blood: Racial Science and Nazi Ethics. . . 347 WOLFGANG BIALAS

Contributors....................................

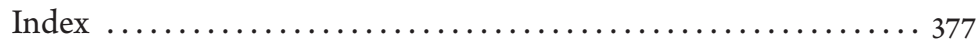




\section{Series Editors' Introduction}

\section{REGNA DARNELL AND STEPHEN O. MURRAY}

Anton Weiss-Wendt, Rory Yeomans, and the contributors to this collection of essays explore the complex story of how eugenics and race as opposed to culture and class became the touchstones of German anthropological science during the Second World War (1939-45 in Europe). Nazi science placed remarkable value on anthropological justification for its policies of genocide, and the discipline, not only in Germany, still struggles with its complicity. These issues are usually framed for English readers in terms of Anglo-American responses to Nazi and Holocaust literatures, from outside what are judged to be the unambiguously deplorable misuses of science in the service of ideology and pragmatic politics. An ocean of separation from Europe, at least at the time, allowed American protestations of innocence, despite its own considerable development of eugenics and scientific racism.

This collection presents detailed case studies of how racial science was adapted to local conditions in a wide variety of European nation-states within the Nazi sphere of influence. The internal variability and cultural specificity of these cases have hitherto been invisible, especially outside Europe, because we have inherited a simplistic and unnuanced narrative of the Holocaust and the science underlying it.

Hitler's racial science was by no means confined to Germany, although its intellectual underpinnings arose from the international hegemony of the German research universities. These essays demonstrate how satellite states acted as active participants in defining racial science in relation to local agendas. In no 
case was the national ideology coextensive with that of Nazi Germany; yet in each country local issues found fertile ground for the pursuit of national identity and autonomy based on German racial science as translated into local terms. Motives, negotiations, bureaucratic regimes, and outcomes varied sharply in Denmark, Italy, Austria, Latvia, Estonia, Hungary, and Romania. Contemporary scholars from each of these national traditions often come to the comparative task with an anthropological or ethnographic mindset. By contrast, agency at the periphery is the common problem that unites this set of essays into a sustained critique of the arbitrary restrictions of scholarship that is confined by the national boundaries and official languages of particular nation-states. Europe in Hitler's time, as in our own, displayed a fluidity of communication - political, social, economic, and cultural - that renders any exclusively national analysis incomplete.

Race is also a quintessential American problem, one deeply embedded in the subconscious of American anthropology. During the years leading up to World War II, North American anthropology explored the autonomy but inextricability of race, language, and culture as ways of classifying the diversity of humankind. It was Franz Boas, himself an early product of the very German higher education system that produced Hitler's race theory, who deconstructed the typology of race and demonstrated the plasticity of racial types. His 1911 The Mind of Primitive Man remains a trenchant critique of scientific racism and eugenics, in part because it insists on seeing human culture and human biology as sides of a single coin. In any case, Boas's anthropology was directed to questions of immigrant assimilability rather than of permanent minorities that threatened the ostensible homogeneity of majority populations in European nation-states where the German Romantic tradition supposed a "genius" of one and only one folk (Volk) per nation. Eugenics rather than genocide was the permanent solution envisioned by scientific racism.

The questions opened up by this comparative analysis frame antisemitism and genocide in local terms that varied across European nation-states. The broad effect of Nazi racial science, then, is perhaps best understood as providing a focus point for multiple smoldering resentments based on ethnicity and race; these were played out radically under a regime that privileged the "othering" of some groups, to the point where they were not fully human, and lent the stamp of science to violent intolerance. Demography, history, internal diversity of region, ethnicity, and local circumstance all determined particular outcomes within the umbrella of Nazi racial science. 


\section{Acknowledgments}

This volume traces its origins to the conference "Racial Science in Hitler's New Europe," which was held at the Center for the Study of the Holocaust and Religious Minorities in Oslo, Norway, in October 2009. The conference was cosponsored by the center and the University of Oslo. We would like to take this opportunity to thank all those at the center in Oslo who contributed toward the conference (listed alphabetically): Kari Amdam, Georg Andreas Broch, Terje Emberland, Odd Bjørn Fure, Ann Elisabeth Mellbye, Ewa Maria Mork, and Maria Rosvoll. A special thank-you goes to Jorunn Selm Fure of the University of Oslo, who enthusiastically embraced the idea of a conference and actively participated in all the stages of its planning. 


\title{
Abbreviations
}

\author{
CUlano Commissie tot Uitzending van Landbouwers \\ naar Oost-Europa (Commission for the \\ Employment of Farmers in Eastern Europe) \\ DNSAP Danmarks Nationalsocialistiske Arbejder Parti \\ (Denmark's National Socialist Workers' Party) \\ ERR Einsatzstab Reichsleiter Rosenberg \\ (Operations Staff Rosenberg) \\ ERÜ Eesti Rahva Ühisabi (Estonian Relief Agency) \\ HSSPF Höhere ss-und Polizeiführer (Higher ss and police leader) \\ KWI-A Kaiser Wilhelm Institut für Anthropologie, menschliche \\ Erblehre und Eugenik (Kaiser Wilhelm Institute for \\ Human Heredity Sciences and Eugenics, Berlin) \\ Move Magyar Országos Véderő Egyesület (Hungarian \\ National Defense Association) \\ NOC Nederlandse Oost Compagnie (Dutch East Company) \\ NSB National-Socialistische Beweging (Dutch Nazi Party) \\ NSDAP Nationalsozialistische Deutsche Arbeiter Partei (National \\ Socialist German Workers' Party [Nazi Party]) \\ NSDAP-N Nationalsozialistische Deutsche Arbeiter Partei- \\ Nordschleswig (National Socialist German \\ Workers' Party, North Schleswig Branch) \\ RAVSIGUR Ravnateljstvo za javni red i sigurnosti (Directorate for \\ Public Order and Security, Independent State of Croatia) \\ REM Reichserziehungsministerium (Reich \\ Ministry of Education)
}




\begin{tabular}{|c|c|}
\hline RFSS & Reichsführer-ss (head of the ss [Heinrich Himmler]) \\
\hline \multirow[t]{2}{*}{ RKF } & Reichskommissar für die Festigung deutschen \\
\hline & $\begin{array}{l}\text { Volkstums (Reich commissioner for the strengthening } \\
\text { of Germandom [Heinrich Himmler]) }\end{array}$ \\
\hline \multirow[t]{2}{*}{ RKo } & Reichskommissariat Ostland (Reich \\
\hline & Commissariat Ostland) \\
\hline \multirow[t]{2}{*}{ RKU } & Reichskommissariat Ukraine (Reich \\
\hline & Commissariat Ukraine) \\
\hline \multirow[t]{2}{*}{ RMO } & Reichsministerium für die besetzten Ostgebiete (Reich \\
\hline & Ministry for the Occupied Soviet Territories) \\
\hline RSHA & Reichssicherheitshauptamt (Reich Security Main Office) \\
\hline \multirow[t]{2}{*}{ RuSHA } & Rasse-und Siedlungshauptamt (Race \\
\hline & and Settlement Main Office) \\
\hline SA & Sturmabteilung \\
\hline \multirow[t]{2}{*}{ SK } & Sonderkommando (subunit of the mobile \\
\hline & killing units of the ss [Einsatzgruppen]) \\
\hline ss & Schutzstaffel (Nazi elite force) \\
\hline \multirow[t]{2}{*}{ TDSPI } & Tautas dzīvā spēka pētī̌sanas instituts (Institute \\
\hline & for Research on National Vitality, Latvia) \\
\hline \multirow[t]{2}{*}{ TDSVDK } & Tautas dzīvā spēka veicināšanas darba kopa (Working \\
\hline & Group for the Advancement of National Vitality, Latvia) \\
\hline $\mathrm{u}$ & Tartu University, Estonia \\
\hline
\end{tabular}




\section{Racial Science in Hitler's New Europe, 1938-1945}




\section{Introduction}

\section{The Holocaust and Historiographical Debates on Racial Science}

\section{ANTON WEISS-WENDT AND RORY YEOMANS}

It is now thirty years since the publication of Bernt Hagtvet, Jan Petter Myklebust, and Stein Ugelvik Larsen's Who Were the Fascists? ${ }^{1}$ As stated in their introduction, one of the objectives of the book was the creation of an international network of scholars interested in the social history of fascism. Much has changed during the past three decades, both in scholarship and in the wider world. The dominant scholarly discourse under which many of the East European contributors to the book operated-Marxist historiography — has vanished along with the Communist countries to which they once belonged. Simultaneously, social history has been superseded by cultural history as the dominant tool for the study of totalitarian regimes. Nonetheless, the history of Nazi Germany and specifically the Holocaust is one field of research that has demonstrated continuous scholarly interest in modernization. ${ }^{2}$

Zygmunt Bauman was one of the first scholars to argue that the Holocaustand by extension the racial theories that underpinned it — was "genocide with a purpose." Eradicating populations, he contended, was not an end in itself but a grand vision of a better and different kind of society. For Bauman, "modern genocide is an element of social engineering, meant to bring about a social order 
conforming to the design of the perfect society." In his now-famous metaphor of landscaping the human garden, physical destruction appears as a necessary chore of weeding, which can be framed as a creative process. Thus, Bauman wrote, "All visions of society-as-garden define parts of the social habitat as human weeds. Like all other weeds, they must be segregated, contained, prevented from spreading, removed and kept outside the society boundaries; if all these prove insufficient, they must be exterminated."

The issue of modernity has defined the study of society in Nazi Germany from the end of the 1960 s onward. While some earlier studies attempted to place the social history of the Third Reich firmly within the context of racial politics, others examined aspects of modernization and everyday life such as consumerism, leisure, tourism, and architecture divorced from the Nazis' racial agenda. ${ }^{4}$ Among the sternest critics of the new social history were Michael Burleigh and Wolfgang Wippermann. Making a distinction between Nazi racial policy as "reactionary" and its social policy as "progressive" was deeply problematic, in their opinion; indeed, both racial and social policy were symbiotically linked, simultaneously modern and profoundly antimodern. According to Burleigh and Wippermann, race was to supplant class as the primary binding principle in a society with growing cleavages. The Nazis sought to create a racial state by means of modern social policies. Therefore, racial and social policy had to be studied as "an indivisible whole."

One of the major controversies in the study of the Third Reich and the Nazi regime concerned the evolution of the Holocaust. Specifically, scholars probed the extent to which the Holocaust was the result of deliberate policies by the Nazi leadership from the late 1930 s onward and/or how far it reflected a range of external and internal pressures. ${ }^{6}$ While the "intentionalists" were largely political and diplomatic historians who focused overwhelmingly on the personality and ideology of Hitler and suggested a top-down model of Nazi rule, "functionalists" were often social and institutional historians who interpreted the Nazi regime in polycratic terms. The latter argued that the Holocaust was driven by improvisation and the internal struggle for power and therefore came about as the result of pressure from below rather than arbitrary decisions from above. $^{7}$ One of the most influential, if controversial, examples of the functionalist interpretation of the Holocaust was Vordenker der Vernichtung (translated into English as Architects of Annihilation), by Götz Aly and Susanne Heim, published in 1991. Aly and Heim insisted that the explanation for the Holocaust was to 
be found not in völkisch (racial) ideas or academic racial treatises but in the utopian economic, industrial, agricultural, and social programs devised by a new generation of ambitious young agronomists, policy analysts, economists, and social planners in the service of the Nazi Party since the late 1930s. Without the input of these young technocrats, they argued, the campaign against the Jews would not have escalated into industrialized mass murder but likely would have remained at the level of pogroms and massacres. Combining ideas about economic rationalization and social engineering, they linked the genesis of the Final Solution to the push for Lebensraum (living space) and the attempt to create an empire in Eastern Europe. According to Aly and Heim, the Jews were systematically murdered because economic planners considered them to be an obstacle to the transformation of the rural East European population into a modern, urban middle class, which would constitute a support base for Hitler's New Europe. ${ }^{8}$

Aly and Heim contended that elements of everyday routine such as mass tourism and Volkswagen cars were part of the same process that led to genocide. In their view, the Holocaust belonged to the same idea of remaking the world through economic restructuring, the decimation of classes and groups, and working toward the realization of a "modern technocracy." Model landscapes complete with motorways, railway lines, canal projects, and integrated economic and transport systems were as much a part of the landscape of the Holocaust as the barbed wire, watchtowers, and gas chambers of Dachau and Auschwitz. ${ }^{9}$

To advance their thesis, Aly and Heim used, among others, the example of scientific advisers in the General Government for the Occupied Polish Territories and the administration of the Warsaw ghetto. Having determined that the ghetto economy was unsustainable without substantial financial support, those advisers suggested to Governor General Hans Frank that the ghetto and its inhabitants should be liquidated. The removal of the ghetto, they advised, would enable the rationalization and modernization of the Polish economy. Christopher Browning, however, demonstrated the flaws in Aly and Heim's thesis. When arguing for the destruction of the Warsaw ghetto, the General Government's economic advisers (the "productionists") sought to keep the Jewish population alive in order to fuel economic production. This line of argumentation contradicted the wishes of racial experts and much of the occupation authorities, who demanded the destruction of the ghetto population on racial and ideological grounds. As Browning has pointed out, rather than a utilitarian 
tool of economic rationalization, the Holocaust was economically ruinous for the new Nazi European empire, draining manpower and resources. ${ }^{10}$

Nevertheless, Browning conceded that Aly and Heim had demonstrated the significance of social utopia and modernization, in addition to social mobility and ambition, in the genesis of the Holocaust. Furthermore, he sided with both scholars in emphasizing that Nazi planning agencies were marked by conflict, disagreement, factionalism, and competing agendas as far as the treatment of the Jews was concerned. ${ }^{11}$ Historians such as Burleigh and Wippermann agreed that, by their very nature, Nazi power structures were diffuse and that the regime encountered pressure from working-class constituencies, especially on issues related to social mobility. However, while insisting that local dynamics had induced the policy of Lebensraum in the East and the Holocaust, Burleigh and Wippermann argued that social pressures could not be separated from the racial agenda. ${ }^{12}$ To underscore this nexus, this volume explores the development of racial science under Nazi rule from a broader perspective. In the main, the essays demonstrate that while the Final Solution was ostensibly informed by racial and national aspirations, these ideals in turn were affected by wider societal processes that played an important role in the creation of a utopian society and in building consensus.

\section{Positive Eugenics into Racial Science: Defining the Terms}

Racial theory, as it came to be known, developed during the nineteenth century through a collective effort of European scientists and thinkers. In a tumultuous period of social and political change, the offer of finding immutable characteristics in humans gave extra credence to experimental science. The determination to classify all flora and fauna in the world inevitably led to the idea of redefining the place of humanity in nature. It appeared only natural that the great variety of cultures, languages, and physical features had to be explained. One of the most striking ideas advanced by Charles Darwin in his On the Origin of Species by Means of Natural Selection (1859) was that of struggle for survival. The term survival of the fittest was further popularized by English social scientist and philosopher Herbert Spencer. Arthur de Gobineau readily conflated linguistic families with racial types to conclude that mixing of races led to degeneration, gradually decreasing the quality of blood. In his pioneering Essay on the Inequality of the Human Race (1853-55), Gobineau cast race as the primary moving force of world history. 
The word eugenics, coined by the British statistician Francis Galton in 1883, denoted selective breeding both for promoting favored characteristics and for eradicating features deemed harmful. Eugenics effectively merged anthropology, Darwinism, and medicine into something German scientists later termed "racial and social biology." The German eugenics movement emerged in the late nineteenth century in response to the supposed "degeneration of the human species." The German term Rassehygiene (racial hygiene) had a broader scope than the English word eugenics and loosely meant the hereditary improvement of a population or all of humanity.

As difficult to capture is the meaning of the word Rasse, which, according to German eugenicist Alfred Ploetz, signified any interbreeding human population that, over the course of generations, demonstrated similar physical and mental traits. Whereas Ploetz was the first to start using the term Rassehygiene, Wilhelm Schallmayer was the first German scholar to publish a treatise on eugenics, in 1891. Schallmayer introduced the cost-benefit analysis theory, which later came to dominate the race hygiene movement. He saw a direct correlation between the biological vitality of the nation and the scope of state power. Neglect of the hereditary fitness of the population would allegedly have a negative impact on politics and could eventually result in the downfall of the state, according to Schallmayer. German zoologist Friedrich Ratzel interpreted Darwin's theory of evolution as the violent struggle between species for territory. The book that he published in 1904 referred to it as Lebensraum. ${ }^{13}$ That same year the first journal ever dedicated to eugenics, Archiv für Rassen-und Gesellschaftsbiologie (Journal of racial and social biology), was founded in Germany by Ploetz. Not coincidentally, eugenics and imperialism have exercised a mutually beneficial relationship. Imperialism provided rich material for eugenics, which supplanted a scientific legitimation for the domination of the "lesser races." By 1900 racial thinking had become a "science." The First World War, marked by the brutalization of warfare and dehumanization of the enemy, only intensified the tendency to think in racial and national terms. ${ }^{14}$ The goal now was no longer preservation of race, but its improvement. Concern shifted from the health of the individual to improving the hereditary fitness of the human race. Consequently, racial progress came to be increasingly interpreted in negative terms as an aversion to racial decline.

Criminal anthropology applied elements of racial theory in practice, making a bridge from physical appearance to mental abilities and to habitual criminal 
tendencies. Coined in 1888 by lawyer Franz von Liszt, the term Kriminalbiologie (criminal biology) suggested that crime was a manifestation of innate characteristics of the offender rather than a reflection of social environment. Although criminal biology predated the Nazis, it acquired scientific currency only after 1933. In effect, criminal law theory was transformed into a concept that was meant to strengthen the vitality of the German people through eliminating "harmful elements" and more vigorous implementation of "racial-hygienic measures." From then on, criminal biology became the preserve of psychologists and medical professionals who focused in their research not on the offense but on the nature of the offenders. Anthropological characteristics of individuals were supposedly enough to determine their predisposition to crime. As a result, a criminal act made an offender a lasting danger to society, someone who could not be resocialized. ${ }^{15}$

Typically, racial scientists came from the medical profession, traditionally seen as the guardian of the health of the nation. In the late nineteenth century academic physicians received much social esteem and, by extension, political importance. Otherwise, German eugenicists were far more heterogeneous than has been assumed in literature. Their scientific interests, personal beliefs, and political allegiances often predated the Nazis. All but a few German eugenicists accepted the superiority of the white race, but so did most of their colleagues abroad. Their ideas of increasing the number of Germany's "fitter" elements and eliminating the masses of the "unfit" were not dissimilar to those of other Western eugenics movements. Hitler's seizure of power, however, instantly placed them in the service of the Third Reich. Eventually, over 90 percent of German anthropologists and eugenicists joined the Nazi Party. ${ }^{16}$ The ideal of a healthier, more productive, and therefore more powerful nation echoed Nazi calls for national revival. As Sheila F. Weiss has emphasized, "Eugenics embodied a technocratic, managerial logic — the idea that power was a product of the rational management of population." ${ }^{17}$

Scholars have noted a remarkable consistency between the views of German anthropologists and Nazi officials. The Nazi seizure of power eliminated the very possibility of any other but a racist interpretation of eugenics. Anthropologists helped to shape Nazi racial policies, either directly or indirectly, while the Third Reich invested significant resources in research that was expected to perfect the human race. Indeed, by the late 1930 s the goals and activities of professional eugenicists came to closely resemble the rhetoric and racial policies of the Nazi 
Party. One of the fundamental Nazi principles - the immutability of human genetic material — came straight from the annals of racial science. However, once racial science had been proclaimed the guarantor of the people's welfare, and by extension the state's welfare, it inevitably became the subject matter of political decision making. The blatant manifestation of that link was the appointment of Heinrich Himmler as Reich commissioner for the strengthening of Germandom (Reichskommissar für die Festigung deutschen Volkstums, or RKF) in October 1939, tasked with supervising the population transfer that followed (Umsiedlung). ${ }^{18}$ Eventually Himmler gained control of virtually every institution involved in both racial policy and organized terror.

Through the blending of the concepts of people and race, the Nazis developed the centerpiece of their ideology - the Volksgemeinschaft (the community of the people). The existence of the völkisch community, however, was predicated on the stigmatization of the "enemies of the people," who were to be excluded, expelled, or annihilated. The Decree on the Protection of the People and the State from February 1933 marked the first attempt at restructuring the relationship between subjects and state. This and subsequent legal acts widened the spheres of private life in which the law could be applied. ${ }^{19}$ However, the Volksgemeinschaft could not be attained through gratification, compliance, terror, and legislation alone. It was a transformative, political process that encompassed the whole of society. Seen from this perspective, the persecution of German Jews was instrumental in destroying civil society and the constitutional state. ${ }^{20}$ Viewed through the prism of race, society was composed not of individuals or social classes but of the Völker (races) that should, with the help of biology and genetics, be segregated into "valuable" and "less valuable." Those defined outside the Volksgemeinschaft did not have the right to enter the community of the chosen few and therefore supposedly aimed at destroying it from within. Jews in the first place were stigmatized simultaneously as a foreign race and Gemeinschaftsfremde (alien to the society). ${ }^{21}$ In equal measure, the preservation of the homogeneity of the German nation "required" the physical separation of Gypsies (Roma). By merging the concepts of Volksgemeinschaft and Kulturkampf, Nazis evolved the idea of Volkstumskampf, that is, racial struggle.

Nazi ideology developed out of the twin concepts of Rasse und Raum (race and space) and Blut und Boden (blood and soil), which encompassed antisemitism and Nordic supremacy on the one hand and eugenics and pronatalism on the other. Resultant policies were supposed to improve the human stock 
by favoring the most "advanced" racial type, the Aryan or Nordic race. Nazi ideologists viewed the pursuit of living space as part of an inevitable racial struggle for existence that was driving human evolution forward. The primacy of that, ultimate, goal had never been in question, despite the oscillation of Nazi policies due to pragmatic considerations. ${ }^{22}$ Euthanasia and forced sterilization in Nazi Germany evolved into a program of mass murder, defined by a deadly mixture of ideology and cost efficiency.

Problematic from the viewpoint of definition, the intricate connection between positive and negative eugenics came to eventually haunt the practitioners of the new discipline. The Nazi agenda further blurred the border between the two. The ban on smoking and extensive cancer research in Nazi Germany, as Robert Proctor has shown, were supposed to benefit only the few select "Aryans" to the exclusion of many, to empower the race rather than improve the health of the individual. ${ }^{23}$ The nutritional intake and health of babies and their mothers of "good blood" in Germany proper, as Götz Aly has vividly demonstrated, were conditioned upon deliberate food withdrawal from the populations of subjugated Eastern Europe. ${ }^{24}$ In retrospect, almost any hygienic measure in Hitler's New Europe that could be loosely evaluated as "positive" had inbuilt negative consequences. Heralded by Hitler's regime as "racial war," the Nazi attack on the Soviet Union in 1941 turned eugenics into an ultimate weapon of destruction on behalf of the Aryan race. It was the image of the superiorly built and mentally attuned "Aryans" defending the white European civilization against the devious, degenerate barbarians from the east that became the epitome of racial science.

\section{Nazi Racial Science and Organic Nationalism in East Central Europe}

Racial doctrine is grounded in existential fear, as illustrated in the European colonial experience in Africa in the nineteenth and early twentieth century. The further European settlers segregated the native populations the more they feared that their own religion and culture were under threat of extinction. Colonial conquest promised instant riches as well as cultural and genetic demise. Colonial discourse builds a bridge from German imperial adventures, which had commonly resulted in massacre, to Nazi racial policies in occupied Europe. Ironically, Hitler was probably the first politician who started speaking of a "New 
Europe." His vision for the continent, however, was drastically different from that of most radical thinkers and scientists of his time. In his programmatic book, Mein Kampf, Hitler infamously stated that the future of Germany lay not in southern and western Africa but in Eastern Europe. Together with the doctrinal transfer came the old fears of the barbarians' revenge.

Rather than the tribal areas of Africa, however, Germans marched through countries with newly won national identities. In fact, in most of the new East and Central European states the nation-building process was still underway. Diaspora minorities, which on average constituted over 10 percent of the total population, were universally viewed as a potential fifth column. It was not only nationalist politicians who wanted to push them over the border or, alternatively, extend the state borders, notwithstanding the obvious contradiction. Throughout Europe, the references to culture were as frequent during the Nazi occupation as they were during the previous period of independence. Coincidentally, in accordance with the existing conventions, the terms English race or Estonian race had been used interchangeably with English nation or Estonian nation throughout the 1920 . In the scholarly writings and popular media of the period alike, the words race, ethnicity, and nationality often meant one and the same thing. Whenever it was conceived of as the struggle for survival, the conflict took on a military, cultural, or even metaphysical form. Although the term Kulturkampf, which was coined by anthropologist and leading left liberal Rudolf Virchow, originally denoted Bismarck's policy toward the Catholic Church, its meaning expanded dramatically. By stressing "natural" difference based on language and culture, organic nationalism lent credence to anthropology. Conversely, hereditary fitness supposedly ensured the long-term survival of a nation and the alleged superior cultural traditions that it embodied. Within this discourse, the Aryan race emerged as the "cultural race" par excellence.

The German Society for Racial Hygiene (Deutsche Gesellschaft für Rassenhygiene) was replicated in the years leading to and immediately after the First World War across East Central Europe. Thus, similar institutions were established in Austria, Czechoslovakia, Hungary, Poland, Romania, Estonia, and Bulgaria, although the specific national context and social and medical practices in those countries did not differ significantly. That was the conclusion of Swiss eugenicist Marie Thérèse Nisot in her comparative study of eugenics published in 1926. Throughout interwar Europe, racial anthropologists and eugenicists enjoyed the status of a constructive force contributing toward the 
creation of the modern nation-state, since their research advanced the program of national regeneration. Dependent on the state for funding, eugenics movements entered a mutually beneficial symbiosis with the state. Regardless of the preferred political structure-a liberal democracy, a peasant state, or a corporatist state-organic nationalism ruled supreme in interwar Europe, while the ethnic majority embodied the idea of a nation-state. Hence the biological laws of heredity promoted by eugenics and racial nationalism seemed to offer the most appealing definition of the state. Eugenics claimed the guardianship of the "biological capital" of the nation, a "healthy body politic" required for a strong nation-state. At the same time, eugenicists promoted a program of national regeneration that would stamp out the proliferation of the "genetically inferior." Notably, when referring to the "unfit" they meant not only people with disabilities but sometimes also individuals of different ethnic origin. Thus national belonging was redefined in biological terms. ${ }^{25}$

From the late 1920s onward eugenics in East Central Europe increasingly looked to German racial hygiene for inspiration. For some countries, the Nazi sterilization law of 1933 served as both a model and the affirmation of the eugenics movement's vitality. The dominance of the German academic tradition was the reason why the majority of East European eugenicists had been educated in Germany and Austria. ${ }^{26}$ Cost-benefit analysis, motivated by the need to reduce the national welfare budget, provided a further incentive for scholars outside Germany to look for a connection between race hygiene and various forms of rationalization. By the mid-1930s the ideological underpinning of the eugenics movement became even more pronounced. The papal 1930 encyclical against the eugenics law and Stalin's censure of eugenic research in the Soviet Union in 1936-37 propelled Nazi Germany to the center of "racial science." 27 The onset of authoritarianism in East Central Europe strengthened state monopoly and promoted corporatism. The subsequent discourse advanced the idea of a planned economy in relation to health policy, introduced in the interests of a nation in possession of high culture. As in the late Weimar period in Germany, eugenics brought with it the promise of economic efficiency and cultural aptitude. In short, it appeared to be a scientific means of solving social and political problems.

What has largely gone unnoticed are the hundreds of scientists and belletrists in the occupied countries of Europe who worked selflessly to implement Hitler's racial plans, although for the benefit of their own countries. Since the end of the First World War eugenicists and racial nationalists in East Central 
Europe had been debating the issue of ethnic minorities, suggesting various solutions, from birth control and sterilization to population transfer. Scientists relied on anthropometry to establish the "racial origin" of various ethnic groups, particularly within the multiethnic context of East Central Europe, and thus their proper place within the national community. The perception of the nation as a racial community - as opposed to a political community-became dominant whenever culture was made the formative element thereof. Culture, however, not only rhymed with nature but often came to replace it. The concept of culture was instrumental in asserting primordial ties within a community. Simultaneously, it advanced the romantic notion of a heroic past with a double emphasis on struggle for freedom and conquest. Coined in 1839, the term ethnography was the confluence of natural and human sciences, meant as a tool in the search for biological and historical origins. ${ }^{28}$

The focus on Nazi Germany has superimposed a notion that racial policies were enforced on the countries occupied or dominated by Hitler's armies. The campaign of mass murder, ingrained in the concept of Aryan superiority, perpetrated by the Nazis in subjugated East Central Europe made any suggestion of indigenous agency appear exceptional and/or exaggerated. Although not totally incorrect, this view seems to ignore local dynamics firmly rooted in the national histories of the great many states that came into existence in the wake of the First World War. In fact, statehood and historical continuity proved to be two potent factors leading to the establishment and promotion of "racial science" locally. Not coincidentally, war served as a consolidating factor for the field of eugenics. The First World War made eugenicists change their perception of warfare as a natural selection process that benefitted the fittest. It simultaneously invited military analogies and contributed to the creation of a truly international eugenics movement. The Nazi conception of racial war recast the Second World War as an exercise in fundamental science carried out by violent means. ${ }^{29}$ In spite of the reality of military occupation or political dependence, semiofficially the Nazi occupation authorities not only tolerated but actually endorsed local academic and scientific research that might have coincidentally advanced Nazi geopolitical goals. The idea of splitting the socalled eastern populations into as many parts as possible (as emphasized by the head of the German Schutzstaffel [ss] and the police, Heinrich Himmler, in his position paper submitted to Hitler in May 1940) was fully compatible with promoting scholarship that could have inadvertently accelerated that process. ${ }^{30}$ 
Suddenly, racial hierarchies that had separated white Europeans from the rest of the world now were being used to redraw boundaries within Europe, Hitler's New Europe. Anxious to carve a piece from the emaciated body of the continent caught in the struggle between "good" and "evil"- the idea pressed home by Nazi propaganda-many occupied European countries developed their own programs for national renewal. This proved to be one idea that united politicians, intellectuals, and scientists on both sides of the ideological dividethose who chose to collaborate with the occupation regime and those who did not. However little trust they placed in Nazi assurances of a brighter future, one thing was clear: democratic, multiethnic states were finished. The promise of racial doctrine was too hard to ignore and too easy to follow. In effect, the occupied eastern territories, as they became known in Nazi parlance, sometimes engaged in a self-destructive process. They thought they were laying the foundation for a sovereign or independent state but in fact they were helping to build the Thousand-Year Reich, grounded in racial superiority.

\section{The American Connection}

In order to better comprehend the uneasy relationship between Nazi racial science and its numerous variations across occupied Europe, it may be useful to briefly look at the interaction between American and German eugenicists prior to the outbreak of the Second World War. Historiographically, in the past thirty or so years understanding of the latter issue has undergone substantial revision, exemplified by the studies of Daniel J. Kevles, Stefan Kühl, and Edwin Black. ${ }^{31}$ From the simple admission that a handful of American scientists, who nonetheless represented the radical-right fringe, had exercised some influence on German racial hygiene, the discussion moved to an examination of the comprehensive exchange of ideas and eugenic policies between the United States and Nazi Germany and to the provocative conclusion that American eugenics paved the way for the Holocaust. Indeed, this connection can be effectively established within the broader context of international eugenics.

American and German scientists played a principal role in establishing the international eugenics movement. The First World War and the vehement opposition of French and Belgian members of the International Federation of Eugenic Organizations prevented their German counterparts from rejoining the fold until 1927. By that time the United States had emerged as an absolute leader 
in eugenic legislation. Since the adoption of the first-ever law on sterilization in Indiana in 1907, thirty-two more American states had followed suit by 1930 . The Immigration Act of 1924, which discriminated against arrivals from Southern and Eastern Europe to the benefit of those from Northern Europe, received a boost in the form of a scientific rationale supplied by American eugenicists. Adolf Hitler was among those who positively commented on "advancement" in population control in the United States. ${ }^{32}$ Nazi racial scientists carefully studied American state legislation before introducing their own sterilization law in 1933. They were quick to note that, unlike in the United States, the German law extended to the whole of the country and served as a preventive measure rather than punishment against criminal offenders.

Scientific cooperation between the United States and Nazi Germany went both ways. Several leading American scholars, most notably the head of the Eugenics Record Office in Cold Spring Harbor, Charles B. Davenport, and his deputy, Harry H. Laughlin, came dangerously close to endorsing Nazi racial policies. Even before Hitler conceived of the idea of a New Europe, Laughlin proposed establishing a world government based on eugenic principles. Davenport fended off criticism by making a distinction between politics and science; Laughlin, meanwhile, proudly accepted an honorary doctorate from Heidelberg University in 1936 yet decided it would be better for his career not to attend the award ceremony in person. American foundations such as the Rockefeller Institute continued sponsoring racial research in Germany (but also throughout Central, Eastern, and Southeastern Europe) after 1933. Mutual praise periodically appeared in professional journals on both sides of the Atlantic throughout the 1930s; a few American eugenicists went to Germany on a study tour as late as 1940. The Japanese attack on Pearl Harbor and the subsequent U.S. entry into the war against Nazi Germany in December 1941, however, put an end to any form of cooperation between eugenicists in the two countries. Laughlin was forced to retire (Davenport had already retired, in 1934) and his laboratory was closed, ceasing its use as a conduit of Nazi racial propaganda. ${ }^{33}$

The American contribution attests to the truly global appeal of eugenics in the interwar years. Much as the Darwinian devaluing of human life should not be regarded as proto-Nazi-as Richard Weikart has insisted-the call for a "biological revolution" was not confined to the Nazis. ${ }^{34}$ Along with the Americans Davenport, Laughlin, Lothrop Stoddard, Clarence Campbell, Madison Grant, and others, Nazi eugenic know-how received enduring support from 
the Norwegian Jon Alfred Mjøen, the Swede Herman Lundborg, the British Cora B.S. Hodson, and many other scholars of international repute who hailed racial research as the science of the future. The first-ever international meeting of eugenicists, in Dresden in 1911, brought together scholars from eight different countries: Germany, the United States, Great Britain, Austria, Czechoslovakia, the Netherlands, Sweden, and Denmark. By the end of the 1930 s the eugenics network had expanded to include five times as many countries and dominions: France, Italy, Spain, Belgium, Switzerland, Norway, Finland, Estonia, Latvia, Hungary, Poland, Mexico, Cuba, Columbia, Guatemala, Venezuela, San Salvador, Uruguay, Chile, Brazil, Panama, Peru, Argentina, the Dominican Republic, Siam, Japan, Australia, New Zealand, Canada, South Africa, and India. A dozen or so countries that had passed sterilization laws in the late 1920 and 1930 s took cues from both the United States and Nazi Germany. André Pichot went as far as to argue that Germany would most likely have implemented sterilization legislation regardless of Hitler's coming to power in $1933 .{ }^{35}$ In fact, the international reputation of eugenics proved very important to the Nazi regime, especially in its early days. Characteristic is a Nazi poster from 1936 that features an "Aryan" family of three holding a shield inscribed with Germany's 1933 Law for the Protection of Genetically Diseased Offspring. The heading "We Stand Not Alone" is illustrated by flags of the nations that had already enacted sterilization legislation. ${ }^{36}$ Conversely, it can be effectively argued that if it had not been for Nazi Germany, the international eugenics movement would not have been able to project its influence indefinitely; by the early 1930 s population studies and genetics, built on a more solid scientific basis, increasingly put eugenics on the defensive.

The preeminence of Nazi Germany in the field of racial science has prompted Stefan Kühl to pose the following, two-pronged question: why relatively many eugenicists, specifically in America, supported Nazi racial policies and why so few opposed them. Even though none of the protagonists could have known that the discipline of eugenics would ultimately pave the way for mass murder and genocide, Kühl's conclusion remains partially valid for this volume as well. Originally the eugenics movement was meant to promote the national cause. Thus the Nazis did not have the prerogative on the policy of race improvement; national, political, and scientific peculiarities shaped perceptions of eugenics in individual countries during the interwar period. At the same time, Nazi scientists had, for the most part, succeeded in ensuring their approach domi- 
nated the international eugenics movement. The stronger the Nazi regime, the more circumspect became international criticism of its policies and the more effectively it could deflect that criticism. Many eugenicists viewed Nazi policies as the triumphant embodiment of their own scientific and political goals. With regard to the Nazi sterilization law, many eugenicists specifically pointed out its comprehensive scope and scientific foundation. Social conservatism, augmented by the antidemocratic tendency among eugenicists, as it had transpired in eugenic literature, resonated with the resolute implementation of the law in Nazi Germany. The ill-defined correlation between positive and negative eugenics enabled advocates of racial science always to strike a discursive balance between the two. As late as 1942, for example, the American geneticist T. U. H. Ellinger in the Journal of Heredity explained away the persecution of Jews in Germany as a "large-scale breeding project." ${ }^{37}$ The relationship between science and politics in the programmatic function of eugenics made it equally easy to impress the argument depending on the circumstances. In short, what was ideally supposed to make racial science advance human progress in reality reintroduced barbarism; the ambiguity surrounding eugenics' principles opened up to interpretations that were effectively utilized by the Nazi regime to advance its destructive visions. Along the way, the eugenics movement's ideas helped to legitimate various nationalist ideologies in Europe, both inside and outside Germany, before and after the Nazis began building their racial empire. Among the critics of Nazi eugenics were socialist eugenicists, particularly from Great Britain, France, the Netherlands, and the United States, as well as scholars who had fled persecution in Germany. Yet reform eugenicists never came to resemble anything like a common front against the Nazi racial project.

\section{Redefining the Agenda for the Study of Racial Science}

Recent decades have seen renewed interest in the history of racial science and eugenics, especially during the Second World War. Indeed, numerous studies have been published on the history of eugenics in Nazi Germany, the campaign of euthanasia against people with disabilities in particular. Despite that, there has been relatively little comparative analysis of Nazi racial policies in the occupied territories, especially in East Central Europe. The traditional literature on the Nazi occupation has tended to paint a conventional picture of compliant and collaborative regimes obediently doing the bidding of the Nazi rulers. 
More often than not, many of the regimes and states that collaborated with the Nazis have been portrayed as possessing an ideology and outlook rooted in Nazi ideas of race and nation that had no resonance in national culture and therefore enjoyed little support among the local population. At the same time, scholars have often advanced a top-down analysis of racial science and racial policy in the occupied territories, focusing on decision makers and supreme rulers, to the disregard of the diverse means by which these ideas were received by the general population, interpreted by local and national ideologues, or implemented by bureaucrats at the lower level. Hence the lack of comparative analysis of the role that idealism and social mobility might have played in the implementation of a racial agenda under Nazi occupation.

The thirteen chapters that make up this volume pursue three main avenues of inquiry. First, they explore the connections between racial science in Hitler's Germany and similar ideas and intellectual trends pursued in the Nazi-occupied or Nazi-dominated countries of Europe by establishing numerous links at the level of scientific exchange, ideological borrowings, institutional or individual collaboration, and policy making. Second, they probe the continuity between scientific developments in various parts of Europe before and during the Second World War. Indeed, both positive and negative eugenics were given even greater priority under the conditions of Nazi occupation. In this context, to determine what changed may be as important as to establish what remained the same. ${ }^{38}$ Finally, they trace the pursuit of a racial scientific agenda in each of the cases under discussion to peculiarities of national history and culture. Undoubtedly, the collective reading of history and its projection into Hitler's future New Europe helped to mold racial science into a respectable field of studies, no matter what the long-term consequences might be. Racialization-the construction of race-intentionally invited the recasting of national history in racial terms and overemphasized its own cultural mission. Despite the temptation to attribute the appeal of racial science solely to the rise of the Nazi Party in Germany, it enjoyed much wider currency throughout Europe than many scholars have been willing to admit. Rather, the Nazis capitalized on preexisting sentiments and pseudoscientific interpretations to promote their program of radical restructuring of the ethnic map of Europe.

This volume advances several theses that challenge the traditional interpretations of racial science and racial politics as applied throughout Germandominated Europe. First, racial science was a prominent feature of population 
policies throughout interwar Europe, including the territories that were later occupied by or allied with Nazi Germany. Efforts to define and manage various population groups - ethnic minorities in particular - in biological terms stemmed from the local context. Due to the sheer amount of resources and credence invested in negative eugenics in Nazi Germany, however, it was only natural for scientists and nationalist politicians from other parts of Europe to look to their German colleagues for guidance and inspiration. Although their objectives and means were not identical, the existential fear that fueled racial science permeated the entire European continent. Therefore, it proved relatively easy for the Nazis to ensure the cooperation of racial scientists (as well as ethnologists, linguists, archeologists — scholars who worked toward preservation of the national heritage) in the occupied territories.

Second, Nazi divide-and-rule policy extended into the academic and scientific disciplines. The "racial value" assigned by the Nazis to any given national group defined the limits within which the latter could operate, including the pursuit of an independent research agenda. Creating hierarchies within hierarchies may represent by far the biggest paradox of German rule in Eastern Europe. Looking from a contemporary perspective, most unexpected was that the local elites genuinely believed in the promise of race as an escape route from the multifaceted crises facing their nations. To find another ethnic group that could be categorized as racially inferior to one's own was both emotionally liberating and politically promising. The idea of the ethnically based transformation of society expunged the nightmare of degradation and emasculation. It simultaneously fed into foundation myths and personified the onward march of modernization. Most important, the drive for racial purity appeared to many intellectuals as the epitome of originality and the avant-garde, a notion encouraged by the Nazis. Racial science, organic nationalism, and radical policies came to reinforce each other in a pursuit of a purer, or rather purified, society.

Third, local support for eugenic and racial ideas was a multifaceted as well as multicausal phenomenon. While ambition, career aspirations, and a desire for social mobility certainly motivated many young scientists and intellectuals to embrace Nazi eugenic and racial scientific ideas, idealism and utopianism were often as important factors. Contrary to traditional narratives of eugenics and racial science as an end in itself, these disciplines also contributed to the radical restructuring of society through social engineering. The cumulative radicalization of racial policy in Nazi Germany, as well as in the satellite states, 
was a result of the influence and ideas not only of leading racial ideologues but also of lower-ranking bureaucrats, intellectuals, and policy analysts. While the idea of polycratic rule has long been recognized as part of the power structure in Nazi Germany, it applies in equal measure to Nazi satellites during the Second World War.

Fourth, because power relationships often remained in a state of flux, radical regimes were frequently able to use the Nazi occupation to further their own short- and long-term goals, sometimes divergent from those of the Nazis. While the Nazi occupation authorities used their power and influence to achieve their own political, strategic, racial, and economic goals, they were forced to work with regimes and societies that had very different agendas. Otherwise, there was only limited resistance to the racial ideas and policies of the Nazi occupation authorities. Indeed, opposition to Nazi racial, biological, and eugenic ideas was not always synonymous with "moderate" views on race and nation. Paradoxically, many of the most extreme advocates of racial purification and transformation were also among the strongest opponents of Nazi euthanasia and eugenics.

Fifth, as long as we are dealing with the problem of motivation, it makes little sense to divide the diverse group of academics, thinkers, scientists, officials, and politicians - all those who ever expressed their opinions on the merits of racial science-into set categories based on their reading of eugenics. The messy administrative structure and the sheer ethnic, geographic, social, and political diversity of Hitler's New Europe prevented the emergence of specific schools of thought with a mass following. Besides, the conditions of Nazi occupation and the war of extermination made the very notion of pure science obsolete. Particularly in the case of racial studies, which had traditionally aspired to policymaking, its practitioners came to view it literally as applied science. Theirs was an experiment, an experiment in existential survival, and as such had countless variations. The term kämpfende Verwaltung — a kind of political fighting administration exemplifying a proactive approach to governing — that Michael Wildt has used with regard to the Reich Security Main Office (Reichssicherheitshauptamt, or RSHA), equally well captures the self-imposed mission of the racial scientists. ${ }^{39}$

This divergence prompts the question of whether it makes sense to talk about racial science at all. With hindsight, scientific racism would be the most accurate term to use, whereas to account for all of its too-numerous variations, 
racial studies may appear an even better construct. One could go one step further and declare the race-related exploits pseudoscience, which they effectively were. However, such linguistic precision may prove counterproductive when it comes to answering the question of why the study of race and the practical application of its findings enjoyed such a broad appeal across Nazi-occupied Europe. Without buying into euphemistic language, it is important to recognize that for practitioners of racial science what they did professionally certainly constituted science. It is this, nearly universal, belief that experimental science could, and should, correct perceived imbalances in humanity that guided their action. Thus, to better understand their motivation we have to look at the larger picture and, wherever possible, through their eyes. The diverse use of terms such as race, racial, and racism by the contributors to this volume reflects the heterogeneity of national experience under Nazi occupation and the divergent conceptions of eugenics that informed those experiences.

The peculiarity of racial science as a body of knowledge was its intricate connection to politics and policymaking. From the outset, academics and scientists engaged in eugenic theorizing and research, seeing themselves as the agents of social change. As one of the most influential German racial scientists, Lothar Loeffler, remarked in 1934, eugenicists should not hesitate to draw political conclusions from their research. ${ }^{40}$ In other words, new scientific knowledge legitimized the political program of the eugenicists (more often than not built around the perceived threat of racial mixing). In the age of the nation-state, however, apart from a few American foundations that had supported that kind of research, for it to have any long-term impact, eugenics could be implemented only from above. Initially perceived as a handicap, and occasionally a point of criticism, the link between racial science and state power reached a whole new dimension with the emergence of Nazi Germany in 1933. As several scholars have pointed out, the major appeal of the Nazi regime to eugenic circles in North America and Western Europe lay less in its particular brand of racial science than in the might of a state that had unequivocally championed its causeindeed, the state that was built on racial principles. Even the starkest critics of the Nazi regime among reform eugenicists, as Stefan Kühl has contended, attacked only its discriminatory treatment of minorities, specifically the Jews, but never questioned the premise of race improvement per se. ${ }^{41}$ In short, they clung to the ephemeral notion that negative and positive eugenics were two worlds apart that never intersected. ${ }^{42}$ In consequence, this made it possible for 
them to reconcile with certain elements of Nazi racial policy without claiming any intellectual affinity to Nazi racial ideology — the paradox that underlined the pursuit of racial science in Hitler's New Europe. In retrospect, racial science was successful only as a policy.

The connection between eugenic research and its political implementation justifies, in our opinion, approaching racial science during the Second World War as a complex project not limited exclusively to professional scientists and academics who built their career within this particular field. As intended by its practitioners, racial science truly became a guiding principle backed by the might of the Nazi state and various indigenous agencies. It stopped being the realm of the select few, confined to their writings and conference papers, and became at once theory and ideology, policy and reality. Inevitably, individual contributors, and the volume as a whole, grapple with the issue of ethics. Yet this collection of essays goes beyond the dilemma of applying scientific findings extracted by coercive means - inflicting pain or suffering in the name of knowledge, universally perceived as the common good. ${ }^{43}$ The case studies discussed in this book relate the pursuit of experimental science to, among others, national foundation myths, the status of minorities, nationalist rhetoric, border disputes, and local and international politics. Predictably, this multilayered interrelation took on a new quality during the Nazi occupation. However local context might have shaped it, as a comprehensive project racial science had a cumulative effect of life redistribution. Willing or not, all those who took part in that project advanced its ultimate objective of race improvement.

As with many other aspects of Nazi ideology, the concept of "rational selection" entailed a contradiction. In order to build a modern, racial state, Nazi social engineers recast the asocial individuals created by industrialization in biological terms. However, the seemingly symbiotic relationship between processes of modernization and eugenics was less evident in the European states that came under German control. In most cases eugenic and racial thinking was driven more by concerns about national survival than a grand utopian vision comparable to the one envisaged by the Nazis. Similar to Robert N. Proctor's observation regarding the earlier eugenics movement in Germany, its ideology in other parts of Europe was less racialist than it was nationalist or meritocratic. The gradual takeover of the German racial hygiene movement by the radical right, much like the entire bureaucratic apparatus in Germany, was not necessarily replicated in other parts of Europe. Whenever individual scholars sided 
with their German counterparts in advocating a racial-biological resolution, a majority of the population rarely became a part of the pseudoscientific discourse, let alone had time to internalize it. The fact that the institutionalization occurred in the occupied countries only haphazardly further widened the gap between theory and praxis.

As a broader objective, by advancing a comparative and interdisciplinary analysis of racial science and eugenics this volume aims to better integrate East Central Europe into the mainstream of Holocaust research and the history of the Second World War. Despite a number of fine monographs dealing with the history of racial science in interwar East Central Europe, and quite a few case studies of the Holocaust published in the past decades, we are lacking a synthetic work encompassing the entire Nazi-dominated continent. By scrutinizing the conventional narrative of both Nazi racial science and occupation policies during the Second World War, this volume surveys a range of countries and ideologies whose relationship to the discussion of the Third Reich and Nazi racial science has remained peripheral at best.

\section{Designing the Perfect Society: Racial Science, Resistance, and Social Mobility}

The essays in this volume strike a balance between functionalist and intentionalist interpretations of the Holocaust and racial science. Several essays expose the factionalism and discord at the heart of many of the Nazi agencies dedicated to the implementation of racial politics in the new empire. A number of contributions highlight the tensions and conflicts accompanying policy making that existed in Nazi agencies such as the Racial Office of the Race and Settlement Main Office of the ss (Rasse-und Siedlungshauptamt, or RuSHA) and the Reich commissioner for the strengthening of Germandom. At the same time, they illustrate the extent to which many of the disputes - routinely framed in the language of scientific integrity - served to conceal another, ambition-driven agenda of racial theorists, scientists, academics, and bureaucrats to remake the Nazi empire in their own image. Furthermore, they demonstrate the willingness of academics and scientists to work with Nazi agencies intimately engaged in the implementation of the Final Solution for what they considered to be the greater good of humankind.

In his chapter Thomas Mayer advances a comparative analysis of three Aus- 
trian universities - Graz, Vienna, and Innsbruck — tracing the evolution of racial and eugenic studies in each. Mayer looks at how professional and institutional ambitions and frustrations affected the relationship between Nazi occupation and racial science. He compares the earlier attempts by racial scientists, anthropologists, and eugenicists to establish a eugenic center in Austria and the opportunities that opened up following the 1938 Anschluss. To realize their ambitions, however, Austrian racial scientists had to compromise their professional integrity by providing scientific support and intellectual legitimization to the Nazi campaigns of euthanasia and sterilization and pathological examinations of prisoners of war.

Like the pioneering work of Aly and Heim, a number of the contributions in this collection demonstrate the symbiosis of racial and nonracial agendas in the formulation and implementation of racial policy. Thus, Isabel Heinemann examines the ss policies of racial categorization, forced population transfer, and mass murder in the German-occupied East. Heinemann argues that despite divergent dynamics the main factor driving mass expulsions of populations and genocide was racial homogenization in the nascent Nazi empire. While the brutal population policies in the East certainly widened the scope of genocide by advancing the racial categorization of a significant proportion of the local population, it was more than just a response to war, Heinemann argues. Moreover, many of the racial theories that the Nazis implemented during their colonization of Eastern Europe had been part of the mainstream discourse in German racial science and anthropology long before 1939. Nonetheless, Heinemann contends that another important factor driving Nazi racial policies in the East was the attempt to establish a socially and economically viable empire populated by a new elite of ethnic Germans and German settlers from the Third Reich.

As with most ambitious colonial projects throughout history, from the beginning the Nazi racial science program was marked by contestation and resistance on the one hand and support and collaboration on the other, from within as well as from outside. Sometimes the ideas and plans advanced by Nazi agencies and individual officials faced opposition or even active resistance, even among the most ideologically committed party activists and members of the ss. At other times, Nazi agencies were forced to subvert the very ethical basis of Nazism for the greater good of racial science and the perceived survival of the German "race." Amy Carney illustrates these conflicting tendencies in her examination of Himmler's policy to increase the number of children born to 
ss men, thereby enlarging the size of the ss "family" and preserving the Aryan race. This racial imperative prompted several ideological innovations, some of which violated the very ethics on which the organization had been based, and therefore faced opposition from certain Nazi agencies and individual ss officers. According to Carney, the need to increase the stock of "good blood" and win the race war superseded all other concerns: while racial principles could never be negotiated the Nazi moral revolution frequently could.

In his detailed discussion of the existential conflicts within the ss, Wolfgang Bialas deals with the tension between ideology and reality, looking specifically at the role of Nazi ethics and the Nazi moral order in the prosecution of mass murder. Bialas examines the often-conflicting origins, elements, and manifestations of Nazi morality and how the ss reconciled those incongruities to create a moralistic unity. Bialas considers, in particular, how the average ss man was able to separate his self-image as a brave soldier carrying out his duty to the Aryan Volk from both the reality of the mass murder of innocent people as a member of an Einsatzgruppe and his personal conscience.

The Nazi racial program provoked further "internal" conflicts, most notably within the German diaspora. The German minority supposedly belonged to a wider Germanic community of blood and therefore was presented in popular discourse, if not scholarly accounts, as nationally and ideologically monolithic. In reality, however, the Nazi racial science program tended to highlight the tensions, antagonisms, and rivalries within ethnic German communities on the one hand and the German diaspora and the völkisch "motherland" on the other.

Steffen Werther looks specifically at Nazi occupation policies in North Schleswig and the complex relationship between Nazi Germany and the ethnic German minority in Denmark. He analyzes the fortunes of two National Socialist parties in Denmark between 1933 and 1945 to trace the shifting political and national allegiances of the German community. He argues that the pursuit of a "Greater Germanic Reich" by Himmler's ss often collided with the aims and aspirations of the German ethnic community in Denmark and the two main parties that represented them. Contesting traditional historiography that presents German ethnic communities in 193 os and 1940s Europe as ideologically homogeneous and receptive toward Nazi völkisch ideology, Werther emphasizes the multiple, and often ambiguous, identities of members of the German minority in Denmark. 
Populations identified by Nazi racial theorists and officials as sharing common Germanic racial and cultural traits had an uneasy relationship with the German authorities. In her case study of the Netherlands, Geraldien von Frijtag Drabbe Künzel deals with the attempts to enlist Dutch peasants and artisans in the German colonization project in the occupied East. She demonstrates how the notion of German-Dutch racial kinship and the idealization of the Dutch farmer as the uncorrupted essence of the Dutch Volk moved from the margins to the mainstream of scholarly and political discussions in the 1930s, actively promoted by ethnologists and anthropologists as well as prominent personalities within the Dutch National Socialist Party. This notion of kinship culminated in the campaign to recruit Dutch willing to resettle in the occupied Soviet territories following the occupation of the Netherlands in 1940. Von Frijtag Drabbe Künzel argues that since both the collaborationist Dutch government and the German authorities believed that the Netherlands was overpopulated, for Dutch farmers to survive, the former were confident that many farmers would enthusiastically embrace the opportunity to start a new life as pioneers in the East. In addition to proving their loyalty to the Reich, the Dutch administration hoped that the colonial enterprise would enable the Netherlands to regain prestige as a colonial power as well as generate economic benefits. The reality of colonization, however, proved far more problematic. The negative experiences of settlers in the East, in particular the tensions and considerable cultural differences between them and both German officials and ethnic German fellow settlers, demonstrated that irrespective of the idealized vision of German-Dutch racial kinship, "Germanic" friendship and solidarity were actually in short supply.

Those identified as the racially purest of Nordic peoples had sometimes the most challenging relationship with the Nazi regime. Terje Emberland examines the evolution of German-Norwegian relations through the prism of Himmler's attempts to create a Norwegian ss unit. He argues that ss policies toward Norwegians were directly influenced by their racial perceptions of Norwegians as primeval Nordic farmers and fierce warriors. As a result, they placed great significance on the success of programs to enlist Norwegian support. In the wake of the occupation of Norway in 1940, Himmler initiated a formal campaign to recruit Norwegians for the ss. Emberland argues that the recruitment campaign had different aims than just providing the military manpower for Nazi Germany. Himmler, along with ss racial ideologists, believed that through recruitment in 
the ss Norwegian men would reawaken their racial, martial spirit. He envisaged that, after proving their mettle in battle, the ss men would return to Norway to form an elite cadre of politicians, policemen, and bureaucrats who would spearhead the transformation of Norway as an ss state; the remainder-peasant warriors making up a new Teutonic Order-would guard the borders of the Nazi empire from the "Asiatic hordes" in the East. As Emberland's chapter demonstrates, despite the effective failure of the recruitment drive, especially in comparison to similar campaigns elsewhere in Europe, the fact that Himmler never abandoned his vision demonstrates the importance of racial conceptions in ss policy toward the Norwegians.

Fascist Italy proves one of the most complex examples of concurrent resistance and acquiescence to the Nazi racial agenda. In her chapter Elisabetta Cassina Wolff looks at the phenomena of racial science and antisemitism in Fascist Italy, which until recently were viewed as contingent, alien, and unpopular innovations borrowed from Nazi Germany for political and diplomatic reasons. Wolff analyzes various racial theories - primarily those of Telesio Interlandi and the young racial theorists who published in his journal, La difesa della razza. She argues that, while support for and a consciousness of racial thinking remained marginal among the general population, from the late 1930 s onward racial ideology became increasingly prominent in Italian intellectual fascist thought. Despite its failure to gain mass popularity, the growing intellectual disputation about race in Fascist Italy nonetheless mirrored wider debates about national identity and the future of fascist ideology. These debates in turn signaled the emergence of a more virulent form of racism as an intellectual reaction to Fascist Italy's colonial wars and the building of a fascist empire in Africa in the 1930 .

\section{Nazi Empire and National Regeneration: Racial Science in Hitler's New Europe}

Several essays in this collection address the impact of the Nazi occupation or of an alliance with Germany on the development of racial science and eugenics in Central, Eastern, and Southeastern Europe. While the rise of Nazism and the political status accorded to individual nation-states within the Nazi empire played an important role in the advance of racial thinking, many of the traditions and ideas that came to the fore in the 1940s existed long before Hitler came to power in Germany. The striking similarity between the issues 
of concern to racial scientists and eugenicists in East Central Europe should be contrasted with the very different social pressures, cultural traditions, and political agendas that drove them. In some cases, such as Fascist Croatia, a basic understanding of Nazi racial science was combined with radical nationalist concepts of race and nation. This created an extreme form of racial politics that even the German occupation authorities were unwilling to support. By contrast, in countries such as Romania, local cultural and scientific traditions contradicted the basic biological tenets of Nazi racial science while using a similar, pseudoscientific language. In Hungary racial science appears to have merely provided "context" for well-established local theories of national and biological origin, culminating in the mass deportation of the Hungarian Jews by the Arrow Cross regime in the summer of 1944 .

The case study of Latvia by Björn Felder illustrates the complex relationship between the Nazi concept of race on the one hand and local nationalist agendas and social pressures on the other. In his chapter Felder examines the evolution of racial science in interwar Latvia and the subsequent period of German occupation. Felder analyzes the genesis of the idea that Latvians overwhelmingly belonged to the "Nordic" race. He does so by tracing the views and scientific projects of leading racial anthropologists at the University of Riga as well as the influence of radical ideologies and movements. He pays particular attention to the campaign of racial purification, negative eugenics, and persecution championed by certain Latvian scientists. A detailed examination of the Institute for the Restoration of National Vitality and its leadership brings Felder to the conclusion that prior to 1941 the Nazi concept of race had little currency within the Latvian scientific community, which emphasized "positive" rather than "negative" eugenics. According to Felder, the shift to negative eugenics occurred only under Nazi occupation. Nonetheless, Felder challenges earlier scholarship, which argued that negative eugenics had been imposed on Latvia as a result of Nazi rule, by demonstrating the utility of negative eugenics to Latvian politicians, scientists, and scholars. The concept of negative eugenics, which was part of the mainstream scientific debate in interwar Latvia, enabled these leaders to differentiate Latvians from citizens of neighboring nations like the Russians and thus escape the "East Baltic" race category.

The eugenic and racial discourse in Estonia was equally shaped by political factors, cultural traditions, and social pressures. Thus Anton Weiss-Wendt demonstrates that eugenic ideas had taken hold in Estonia long before the Nazi 
invasion in the summer of 1941. Ideas about living space, the improvement of the race, "healthy breeding," and the pernicious influence of the Russian minority were part of public discourse as early as the 1920s. By the late 1930 s negative eugenics, including enforced abortion and sterilization of selected group of offenders, were recast as public health policy. Paying particular attention to the career of the anthropologist Johann Aul, Weiss-Wendt describes how Estonian scientists and politicians took advantage of the Nazi occupation to promote their own agenda of expelling the Russian minority and countering the negative stereotype of an "East Baltic" race with the counterimage of a "blond," racially healthy Nordic race. He also details how the research of Aul and other scientists indirectly contributed to Nazi plans for the demographic restructuring of Europe.

A distinction needs to be made between East European countries or specific provinces that fell briefly under Soviet control in 1939-40 (Estonia, Latvia, Lithuania, western Poland, and Bessarabia) and the rest of Nazi-dominated Europe. In the former territories existential fear prompted by Soviet terror became the decisive factor not only in determining political allegiances but also in the willingness to accept, for example, ethnic cleansing as a logical solution to the perceived threat of ethno-national extinction. ${ }^{44}$ The context was obviously different in the case of larger countries, particularly those formally allied with Nazi Germany. Marius Turda examines the role that racial scientists and eugenicists played in the development of racial policy in Hungary between 1940 and 1944. Defining the nation in biological terms, according to Turda, was not merely an oversimplification of racism or a distortion of eugenics. Rather, it should be viewed within the framework of an alternative nationalist project - a new form of cultural and political modernity conditioned by the fusion of mass politics and eugenic utopias of national belonging. Although throughout the 1920 and for much of the 1930 ideas about racial purity were contested, Turda argues that by the time the Hungarian Institute of National Biology was founded in 1940 racial and antisemitic concepts of Hungarian national identity had moved into the mainstream. This was particularly true after the territorial expansion between 1938 and 1941 at the expense of southern Slovakia, northern Transylvania, and the Vojvodina that saw Hungary absorb large non-Hungarian populations. Turda describes how institutions such as the Hungarian Institute of National Biology were used to foster a sense of national belonging in an enlarged state through the concept of "biologism," a holistic 
form of eugenics that fused the concept of biological worth with physical and moral education of the population. It was at this point, Turda contends, that antisemitism, often an aspect of Hungarian racial and eugenic thinking, became a central preoccupation of eugenicists and racial scientists. The renewed centrality of antisemitism in Hungarian racial science culminated in mid-1944 with the official inauguration of a Hungarian Institute for Research into the Jewish Question, which heralded the launch of the Final Solution in that particular country.

While the political alliance with Nazi Germany undoubtedly contributed to the evolution of racial and biological concepts in 1940s Hungary, local biological and racial discourses played a far greater role in this respect. The chapter by Vladimir Solonari examines the similarly entangled history of racial science in Romania. An overview of Romanian eugenics in the 1920 indicates that, despite the introduction of anthropological studies departments at a number of universities, scientific racism was confined to a marginal cohort of Romanian physicians and biologists. According to Solonari, this was partly due to the fact that popular racial theories promoting racial purity and denigrating "mongrel peoples" could not easily be applied in Romania since Romanians believed they were the descendants of Roman settlers and pre-Roman Dacian populations. Given their supposedly mixed-race origins, scientific racism had the potential to undermine the biological self-worth of the Romanians. Solonari shows how national agendas frequently collided with the long-term goals of the Nazis, who experienced difficulties planting racist ideas in Romanian soil despite the emergence of more explicitly biological concepts of ethnicity and race in the 1930 and the seizure of power in Romania by pro-Nazi forces in 1940.

In Croatia, as Rory Yeomans demonstrates in his chapter, the ultranationalist Ustasha regime capitalized on both Nazi racial science and the substantial German presence to pursue its own radical agenda. Yeomans examines racial science and eugenics in the Independent State of Croatia between 1941 and 1945 as it was applied in the program of racial purification and mass murder pursued by the Ustasha regime against the native Serb and Jewish populations. Yeomans examines how the Ustasha regime used Nazi biological conceptions of race to legitimize its campaigns of national and racial regeneration. These conceptions and programs evolved over time, partly under political pressure from the Nazi and Italian occupation authorities and partly as a result of internal political pressures from within the regime itself. 
Yeomans argues that the regime's abandonment of its initial policy of mass murder, deportation, and forced assimilation of the Serb population did not reflect a fundamental change in thinking. Rather, it represented a contingent tactical maneuver. This policy change was frequently contested from within, both from factions in the regime and from the grassroots Ustasha movement itself. At the same time, the pseudoracial and pseudobiological theories that animated the initial program of mass murder and deportation were intermittently revived long after they had been officially abandoned. Meanwhile, with few exceptions, the campaign of extermination against Jews continued unabated. The regime's officials, propagandists, and intellectuals explicitly linked the campaigns against the Serbs and the Jews to wider campaigns of national regeneration, moral purification, social justice, and cultural rebirth. As a result, thousands of idealistic students, young sociologists, anthropologists, and scientists rallied behind the slogan of national regeneration. The very fact that many of the racial and anthropological theories utilized by the Ustasha regime were either drawn from or ascribed to the writing or ideas of nineteenth- and early twentieth-century Croatian (rather than German) scholars and scientists enabled the regime to present its violent revolution as truly national in form and scope.

When analyzing racial science in Hitler's New Europe, as this volume has attempted, one should keep in mind the centrality of the Nazi regime. Nazi ideas of race and science are essential to this discussion for the impact they had not only on the development of society in Germany but also in Europe at large. The essays in this collection reveal as much about identity, race, and nationalism in East Central Europe as they do about Nazism and Nazi Germany-the ideas and utopian visions that preoccupied its leaders, intellectuals, and ideologists. Above all, they expose the diverse thinking that lay behind the grand designs for the new Nazi empire and the role that racial science was to play in this campaign of radical restructuring. Extensive research over the past few decades has opened up new avenues of enquiry into the ultimate social, political, demographic, and racial goals of the Nazi regime. Paradoxically, the more we know, the more ambiguous many of the early interpretations of Nazi Germany and Hitler's new European order appear. The more historical data becomes available, the more questions and problems they pose. Although this collection does not provide a definitive answer, it sheds new light on some of the most important aspects of Nazi racial science, raising a series of ethical, moral, and intellectual questions that are more relevant today than they have ever been. 


\section{Notes}

1. Stein Ugelvik Larsen, Bernt Hagtvet, and Jan Petter Myklebust, eds., Who Were the Fascists? Social Roots of European Fascism (Oslo: Universitetsforlaget, 1980), iv-viii.

2. For an overview of recent scholarship on the connection between Nazi Germany and modernization, see Paul Betts, "The New Fascination with Fascism: The Case of Nazi Modernism," Journal of Contemporary History 37, no. 4 (2009): $541-58$.

3. Zygmunt Bauman, Modernity and the Holocaust (London: Polity Press, 1989), 91-92.

4. Cf. Rainer Zitelmann and Michael Prinz, eds., Nationalsozialismus und Modernisierung (Darmstadt, Germany: Wissenschaftliche Buchgesellschaft, 1991); Winfried Nerdinger, ed., Bauhaus-Moderne und Nationalsozialismus: Zwischen Anbiederung und Verfolgung (Munich: Prestel, 1993); Shelley Baranowski, Strength through Joy: Consumerism and Mass Leisure in the Third Reich (Cambridge: Cambridge University Press, 2004); Irene Guenther, Nazi Chic? Fashioning Women in the Third Reich (New York: Berg, 2004). For a critique of the modernization theory, see Jens Alber, "Nationalsozialismus und Modernisierung," Kölner Zeitschrift für Soziologie und Sozialpsychologie 41, no. 2 (June 1989): 346-65; Norbert Frei, "Wie modern war der Nationalsozialismus?" Geschichte und Gesellschaft 19, no. 3 (1993): 367-87.

5. Michael Burleigh and Wolfgang Wippermann, The Racial State: Nazi Germany, 1933-1945 (Cambridge: Cambridge University Press, 1991), 8-22.

6. The debate between "intentionalists" and "functionalists" is discussed more fully in Christopher Browning, "Nazi Resettlement Policy and the Search for a Solution to the Jewish Question, 1939-1941," and “Beyond 'Intent and Functionalism': The Decision for the Final Solution Reconsidered," in his The Path to Genocide: Essays on Launching the Final Solution (Cambridge: Cambridge University Press, 1992), 3-27, 85-122. In these essays Browning comes down cautiously on the side of functionalism before 1940 while arguing that after 1940 intentionalism was the driving force behind the Holocaust.

7. Tim Mason, "Intention and Explanation: A Current Controversy about the Interpretation of National Socialism," in The Führerstate, Myth and Reality: Studies on the Structural Politics of the Third Reich, ed. Gerhard Hirschfield and Lothar Kettenacker (London: German Historical Institute, 1981), 23-40.

8. See Götz Aly and Susanne Heim, Vordenker der Vernichtung: Auschwitz und die deutschen Pläne für eine neue europaïsche Ordnung (Hamburg: Hoffmann Campe, 1991), 9-18; Götz Aly and Susanne Heim, "Die Ökonomie der Endlösung: 
Menschenvernichtung und wirtschaftliche Neuordnung," Beiträge zur Nationalsozialistichen Gesundheits und Sozialpolitik 5 (1982): 7-90; Götz Aly and Susanne Heim, "Sozialplanning und Völkermord: Thesen zur Herrschaftsrationalität der nationalsozialistischen Vernichtungspolitik," in Vernichtungspolitik: Eine Debatte über den Zusammenhang von Sozialpolitik und Genozid in nationalsozialistichen Deutschland, ed. Wolfgang Schneider (Hamburg: Konkret, 1991), 11-24.

9. Aly and Heim, Vordenker der Vernichtung, 9-18.

10. Browning, Path to Genocide, 59-76.

11. Browning, Path to Genocide, 86-124.

12. Burleigh and Wippermann, Racial State; Michael Burleigh, Death and Deliverance: Euthanasia in Germany, 1900-1945 (Cambridge: Cambridge University Press, 1994).

13. Robert Proctor, Racial Hygiene: Medicine under the Nazis (Cambridge ma: Harvard University Press, 1988), 11-14; Mark Levene, The Rise of the West and the Coming of Genocide (London: I. B. Tauris, 2005), 186-88, 191-92, 197-99.

14. Eric Weitz, A Century of Genocide: Utopias of Race and Nation (Princeton NJ: Princeton University Press, 2003), 36-39, 45, 50.

15. Jürgen Simon, "Kriminalbiologie und Strafrecht von 1920 bis 1945," in Wissenschaftlicher Rassismus: Analysen einer Kontinuität in den Human-und Naturwissenschaften, ed. Heidrun Kaupen-Haas and Christian Saller (Frankfurt: Campus Verlag, 1999), 228-31, 242.

16. Benoît Massin, "Anthropologie und Humangenetik im Nationalsozialismus oder: Wie schreiben deutsche Wissenschaftler ihre eigene Wissenschaftsgeschichte?" in Kaupen-Haas and Saller, Wissenschaftlicher Rassismus, 37.

17. Sheila F. Weiss, “The Race Hygiene Movement in Germany," Osiris 3, no. 2 (1987): 194-95.

18. Massin, "Anthropologie und Humangenetik," 12-64.

19. Michael Wildt, "The Political Order of the Volksgemeinschaft: Ernst Fraenkel's Dual State Revisited," in On Germans and Jews under the Nazi Regime: Essays by Three Generations of Historians; A Festschrift in Honor of Otto Dov Kulka, ed. Moshe Zimmermann (Jerusalem: Hebrew University Magnes Press, 2006), 155-59.

20. Michael Wildt, Volksgemeinschaft als Selbstermächtigung: Gewalt gegen Juden in der deutschen Provinz 1919 bis 1939 (Hamburg: Hamburger Edition, 2007), 361.

21. Michael Zimmermann, Rassenutopie und Genozid: Die nationalsozialistische "Lösung der Zigeunerfrage" (Hamburg: Christians, 1996), 373, 377.

22. Richard Weikart, Hitler's Ethics: The Nazi Pursuit of Evolutionary Progress (New York: Macmillan, 2009).

23. Robert Proctor, The Nazi War on Cancer (Princeton NJ: Princeton University Press, 1999). 
24. Götz Aly, Hitler's Beneficiaries: Plunder, Racial War, and the Nazi Welfare State (New York: Picador, 2008).

25. Marius Turda and Paul Weindling, "Eugenics, Race and Nation in Central and Southeastern Europe, 1900-1940: A Historiographic Overview," in "Blood and Homeland": Eugenics and Racial Nationalism in Central and Southeast Europe, 1900-1940, ed. Marius Turda and Paul Weindling (Budapest: Central European University Press, 2007), 2-8, 10, 12.

26. Turda and Weindling, "Eugenics, Race and Nation," 8-9.

27. Mark B. Adams, Garland E. Allen, and Sheila F. Weiss, "Human Heredity and Politics: A Comparative Institutional Study of the Eugenics Record Office at Cold Spring Harbor (United States), the Kaiser Wilhelm Institute for Anthropology, Human Heredity, and Eugenics (Germany), and the Maxim Gorky Medical Genetics Institute (USSR)," Osiris 20, no.1 (2005): 253-54.

28. Weitz, Century of Genocide, 30-33.

29. The development of eugenics rationale into practice from the First to the Second World War can be illustrated by the extreme ideas of some American and German scholars from 1917 and 1918 to dispatch "idiots" to the front line, where they could surely perish, and the "wild euthanasia" of 1941 and 1942, when the ss Einsatzgruppen executed en masse mental patients in the occupied Soviet territories.

30. Among other things, Himmler suggested,

In handling the foreign ethnic groups in the East we must pay heed to recognize and to show attention to as many separate peoples as possible. ... I want to state thereby that we must have great concern not to unite the people of the East, but to dissect them into as many parts and splinters as possible.... We must dissolve them into innumerable small fragments and atoms.... It must also be possible within a somewhat longer stretch of time, to bring about the disappearance of the ethnical concepts of the Ukrainians, Gorelians, and Lemkians."

Quoted in Helmut Krausnick, "Denkschrift Himmlers über die Behandlung der Fremdvölkischen im Osten (Mai 1940)," Vierteljahrshefte für Zeitgeschichte 5, no. 2 (1957): 194-98.

31. Daniel J. Kevles, In the Name of Eugenics: Genetics and the Uses of Human Heredity (Berkeley: University of California Press, 1986); Stefan Kühl, The Nazi Connection: Eugenics, American Racism, and German National Socialism (Oxford: Oxford University Press, 1994); Edwin Black, War against the Weak: Eugenics and America's Campaign to Create a Master Race (Washington DC: Dialog Press, 2003). 
32. Specifically, Hitler wrote, "The American Union, by principally refusing immigration to elements with poor health, and even simply excluding certain races from naturalization, acknowledges by slow beginnings an attitude which is peculiar to the national State conception." Adolf Hitler, Mein Kampf (Boston: Houghton Mifflin, 1939), 658.

33. For a comprehensive overview, see Kühl, Nazi Connection, and Stefan Kühl, Die Internationale der Rassisten: Aufstieg und Niedergang der internationalen Bewegung für Eugenik und Rassenhygiene im 20. Jahrhundert (Frankfurt: Campus, 1997).

34. Richard Weikart, From Darwin to Hitler: Evolutionary Ethics, Eugenics, and Racism in Germany (New York: Palgrave-Macmillan, 2004), 10.

35. André Pichot, The Pure Society: From Darwin to Hitler (London: Verso, 2009), 179.

36. Reproduced in Proctor, Racial Hygiene, 96. The poster incorrectly identified Estonia as Lithuania, whereas England, contrary to the poster's statement, never enacted sterilization law.

37. Kühl, Nazi Connection, 31, 36, 50, 59-60, 63; Kuhl, Die Internationale der Rassisten, $12,15,34-35,126-27,137-38$. Ironically, the director of the American Eugenics Society, Albert E. Wiggam, used the term biological Holocaust in his popular book to argue against "racial mixing." Wiggam, The New Decalogue of Science (Indianapolis: Bobbs-Merrill, 1924), 15.

38. Somewhat ironically, the comprehensive Oxford Handbook of the History of Eugenics, published in 2010 by Oxford University Press, contains virtually nothing on the Second World War period, effectively treating the years 1939 to 1945 as an aberration.

39. Michael Wildt, An Uncompromising Generation: The Nazi Leadership of the Reich Security Main Office (Madison: University of Wisconsin Press, 2010).

40. Kühl, Nazi Connection, 28, 65-68.

41. Kühl, Nazi Connection, 53, 91-94.

42. Among the critics of this notion is Daniel J. Kevles, who has described the link between positive and negative eugenics as a "two-pronged program." Kevles, "International Eugenics," in Deadly Medicine: Creating the Master Race (Washington DC: U.S. Holocaust Memorial Museum, distributed by the University of North Carolina Press, 2004), 50.

43. Philip Zimbardo's now-famous Stanford prison experiment had to be prematurely discontinued for that very reason.

44. Here we are using Terry Martin's definition of ethnic cleansing: the forcible removal of an ethnically defined population from a given territory. Cf. Martin, “The Origins of Soviet Ethnic Cleansing," Journal of Modern History 70, no. 4 (December 1998): 817-18. 